\title{
The comparative analysis of sprouted legume and cereal based composite diet
}

\begin{abstract}
The influence of sprouting on the chemical and sensory properties of millet (Pennisetum glaucum) and Africa breadfruit (Treculia Africana) based products was evaluated. The composite diets were analyzed for proximate, mineral, vitamin, antinutritional factors and sensory qualities of the composite diets. Based on the result, sprouting increased the moisture (6.09\%)-6.97\%), ash (1.19\%-1.59\%), crude fibre $(2.26 \%-2.56 \%)$, carbohydrate $(50.63 \%-67.31 \%)$, energy (355.45cal-360.05cal), reducing sugar $(2.40 \%-5.17 \%)$ and dietary fibre (43.99\%-55\%). Sprouting also decreased fat $(11.62 \%-7.30 \%)$ and protein $(28.20 \%-16.45 \%)$, which is higher than the protein content of the commercial product $(16.45 \%)$. Starch was also reduced from (7.82\%-4.24\%). Phosphorus was increased (46.78mg/100g-105.9mg/100g), while calcium and magnesium were decreased $(208.17 \mathrm{mg} / 100 \mathrm{~g}-116.53 \mathrm{mg} / 100 \mathrm{~g})$ and $(158.36 \mathrm{mg} / 100 \mathrm{~g}-76.82 \mathrm{mg} / 100 \mathrm{~g})$. The vitamins $\mathrm{C}$, A and $\mathrm{E}$ increased due to sprouting. The phytate, tannin and oxalate levels were reduced. The organoleptic attributes of the diets were improved and the diet samples were acceptable. However, sample A (commercial product NUTREND) was much acceptable probably because people are used to the taste and its wide utilization.
\end{abstract}

Keywords: sprouting, phytate, protein, PEM, NUTREND
Volume 4 Issue 2 - 2017

\author{
Okorie SU, Ekwe CC \\ Department of Food Science and Technology, Imo State \\ University, Nigeria
}

\begin{abstract}
Correspondence: Chiwundu Ekwe Charles, Faculty of Engineering, Department of Food Science and Technology, Imo State University, Owerri, Nigeria, Email chibyzaps@gmail.com
\end{abstract}

Received: April 23, 2017 | Published: November 21, 2017

\section{Introduction}

\section{Background of the study}

In developing countries like Nigeria, protein energy malnutrition $(\mathrm{PEM})$ is endemic. Protein energy malnutrition is more among children because, they are weaned abruptly into starchy foods. The formulation and development of nutritious complementary foods from local and ready available raw materials has received considerable attention in many developing countries. The commercially standardize foods are generally very good and can help meet the nutritional requirements of young children in both developed and developing countries. However, the development of low cost, high protein food supplements for weaning countries where traditional foods used during the weaning process are frequently characterized by low nutrient density and high bulk which can adversely affect infant's health. ${ }^{1}$

Protein energy malnutrition generally occurs during the crucial transitional phase when children are weaned from liquid to semi solid foods, during this period, because of their repaid growth, children need nutritionally balanced, calorie-dense complementary foods in addition to breast milk. Protein-energy malnutrition is wide spread in both rural and urban communities in Nigeria. This is due to strict economic measure, inadequate production and supply of foods especially protein and micro-nutrients rich foods. Global nutrition survey revealed that the most dietary deficit is protein of high biological value. This is because they are expensive and beyond the reach of the majority of the production. However, vegetable protein complements each other, a combination of legume and cereal proteins will have a nutritional value as good as animal protein. ${ }^{2}$

According to Baldi, ${ }^{3}$ protein deficiency cannot be overcome by using animal products as they are not easily affordable. He maintained that the only alternative is to push up the vegetable protein intake which already makes up to $70 \%$ or 50 of world's protein production; there are little advances in the processing and preservation techniques and neglect of our indigenous corps.

The high prevalent rate of malnutrition has led to researches into ways of processing locally available foods to improve their nutritive value and introduce variety in the diet, this will help to meet children who are more prone to malnutrition. $\mathrm{WHO}^{4}$ reported that breast milk is the best for the infants (0-6months) but as they continue to grow, they are gradually introduced to semi-solid and solids foods know as complementary foods. In developing countries such as Nigeria, complementary foods are mainly starchy staples such as maize, sorghum, millet, rice, etc. this is because cow milk of various modifications and artificial complementary foods are expensive and many low income families can afford it. The higher food prices in recent years and the need for protein rich foods have created the need to develop less expensive, more nutritious and ready to serve complementary foods based on edible legumes and cereals.

\section{Problem statement}

Conventional complementary foods in Nigeria are costly and unaffordable to some citizens. Also traditional complementary foods are mainly of starchy products leading to the prevalent rate of malnutrition of the growing population especially children who are more prone to malnutrition.

\section{Justification}

The result of this research work will enlighten mothers both in the rural and urban communities on the method of producing nutritious and cheap complementary foods from sprouted African breadfruit (Treculia Africana) and millet flours. It will also help the government in food policy making and industries to produce more nutritious and 
cheap foods from locally available staple to alleviate the problem of protein-energy malnutrition.

\section{Aims and objectives}

The broad objective is to evaluate the sensory and nutrient composition of formulated breadfruit and millet based foods.

\section{Specific objectives}

i. To produce flour from sprouted and unsprouted millet and breadfruit.

ii. To produce porridge (gruel) from the composite flour.

iii. To evaluate their organoleptic attributes and proximate analysis.

iv. To statically analyze the data gotten.

\section{Materials and methods}

The millet grains, African breadfruit, granulated sugar, crayfish, skim milk powder, salt and nutrend (a commercial brand) was purchased from Eku-Ukwu market, Owerri in Imo State.

\section{Processing of sprouted millet flour}

Three kilograms $(3 \mathrm{~kg})$ of millet grains were cleaned and sorted manually to remove dirt and stones. The millet grains were steeped in the ratio of 1:3 (W/V) in clean water in covered plastic containers for $3 \mathrm{~h}$, this was done for the grains to imbibe water for easier germination. The soaked millet grains were spread on a wet jute bag covered with muslin cloth and another jute bag, was used to cover the grains. The millet grains were allowed to sprout for $48 \mathrm{~h}, 72 \mathrm{~h}$ and $96 \mathrm{~h}$ at the temperature of $28^{\circ} \mathrm{C} \pm 2^{\circ} \mathrm{C}$. Water was sprayed on the grains at $12 \mathrm{~h}$ intervals to keep the germinating grains moist. The grains were turned at intervals to ensure proper aeration and the minimization of mould growth. The sprouted millet grains were derooted, dehusked, washed, sorted and dried at $105^{\circ} \mathrm{C}$ for $1 \mathrm{~h}$ in a Gallenkamp oven drier. The dried sprouted millet grains were separately milled using disc attrition mill and sieved with a $1 \mathrm{~mm}$ sieve size to obtain flours of uniform particles size and stored in a labeled air tight polyethylene bags at room temperature for analysis.

\section{Processing of sprouted breadfruit flour}

Three kilograms $(3 \mathrm{~kg})$ of African breadfruit seeds were cleaned and sorted manually to remove dirt and stones. The breadfruit seeds were steeped in the ratio of $1: 3(\mathrm{~W} / \mathrm{V})$ in clean water in covered plastic containers for $6 \mathrm{~h}$, this was done for the seeds to imbibe water for easier germination. The soaked breadfruit seeds were spread on a wet jute bag covered with muslin cloth and another jute bag was used to cover the seeds. The breadfruit seeds were allowed to sprout for $96 \mathrm{~h}, 120 \mathrm{~h}$ and $144 \mathrm{~h}$ at the temperature of $28^{\circ} \mathrm{C} \pm 2^{\circ} \mathrm{C}$. Water was sprayed on the seeds $12 \mathrm{~h}$ intervals to keep the germinating seeds moist. The seeds were turned at intervals to ensure proper aeration and the minimization of mould growth. The sprouted breadfruit seeds were derooted, dehusked, vashed, sorted and dried. The dried sprouted breadfruit seeds were separately milled using disc attrition mill and sieved with a $1 \mathrm{~mm}$ sieve size to obtain flours of uniform particle size and stored in labeled air tight polyethylene bags at room temperature for analysis (Figure $1 \& 2$ ).

\section{Processing of crayfish flour}

The crayfish was cleaned, sorted, winnowed and dry milled in an electric blender (National, Model Mk 308, Japan). The milled crayfish sample was sieved with $1 \mathrm{~mm}$ sieve size to obtain the flour. The crayfish flour was packaged in labeled air tight polyethylene bag and stored at room temperature. Crayfish contains high protein quality, minerals and vitamins ${ }^{5}$ (Figure 3 )

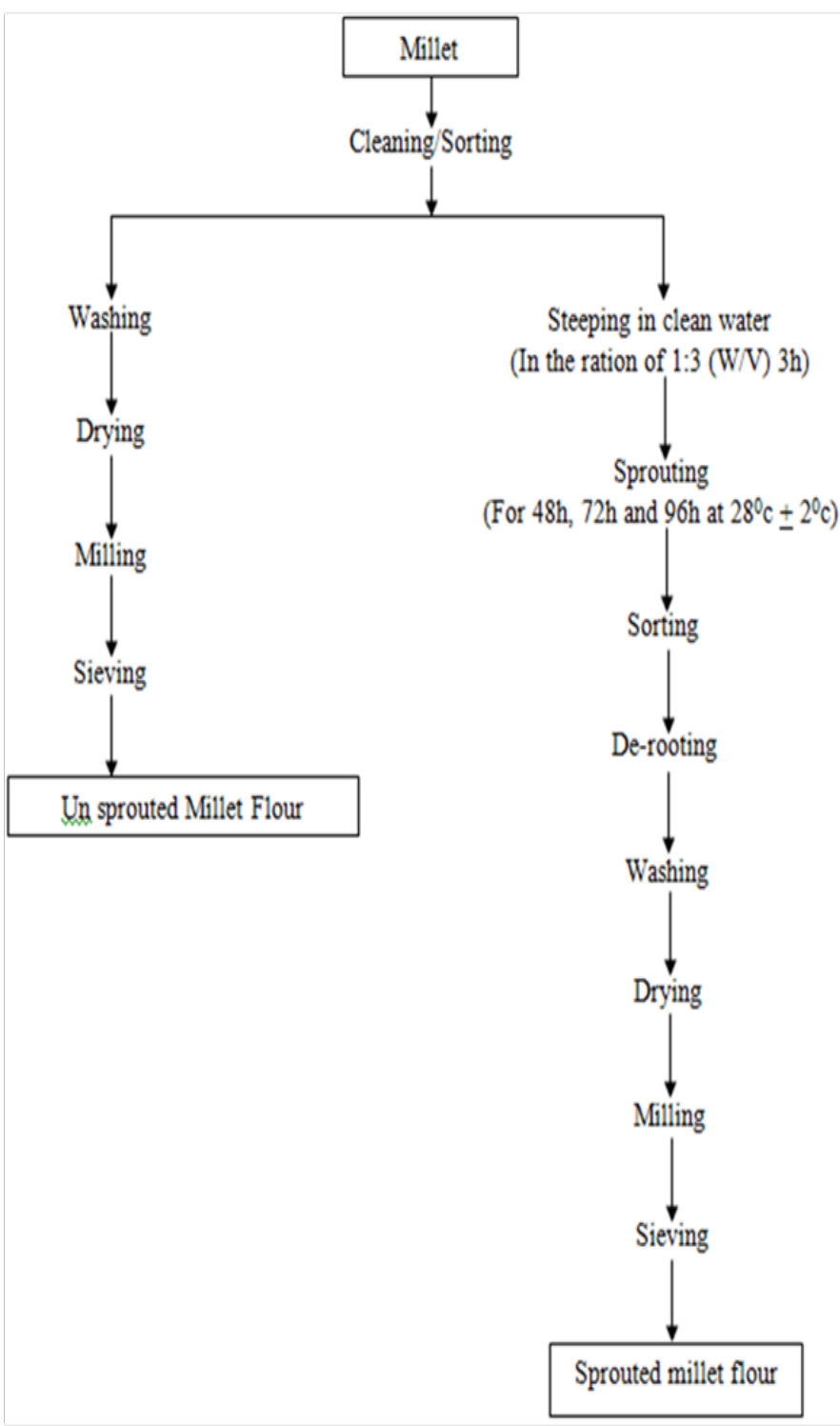

Figure I Flow chart of unsprouted and sprouted millet flour processing.

\section{Preparation of composite diets}

The processed flours were used to formulate composite diets in the ration of $70: 30.70 \%$ was from millet flour while $30 \%$ was from breadfruit flour. The flour samples consist of constant proportions of millet, breadfruit, crayfish skimmed milk powder, sugar and salt (Table 1).

\section{Preparation of porridges/gruels}

The porridges or gruels were prepared from each composite flour using the standard recipe. Flour-100g, Water- 200ml, Sugar-10g.

About $200 \mathrm{ml}$ of cold water was poured in a pot and placed on fire and $100 \mathrm{~g}$ of each flour blend was added into the pot. The mixture was 
cooked for 10-15mins until it thickens and was continuously stirred with a wooden spoon, when the porridge was done; $10 \mathrm{~g}$ of sugar and $20 \mathrm{~g}$ of milk was added to improve the taste.

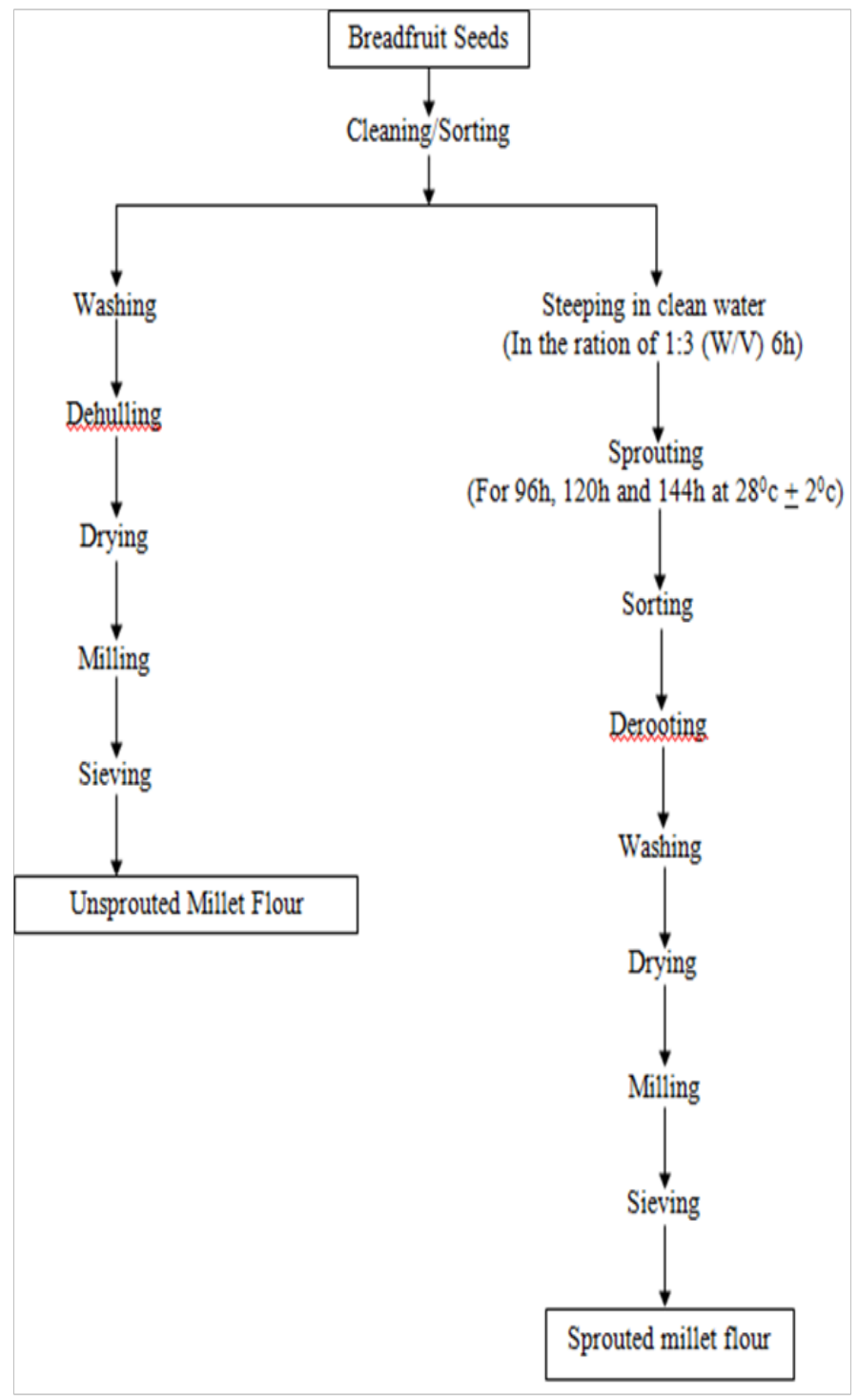

Figure 2 Flow chart of unsprouted and sprouted breadfruit seed flour processing.

\section{Moisture content determination (Line I)}

I. Protein Determination - The method of $\mathrm{AOAC}^{6}$ was used.

II. Fat Determination - The Soxhlet fat extraction method described by Onwuka ${ }^{7}$ was used.

a) Ash determination: The method described by Onwuka ${ }^{7}$ was used.

b) Crude Fibre determination: The crude fibre content was determined using the method as described by Onwuka

III. Carbohydrate determination - was done using the difference method described by Onwuka. ${ }^{7}$

a) Energy content determination: Energy content was determined using the factorial method described by AOAC. ${ }^{8}$ b) Starch content determination: Starch content of sample was determined by sieving described by Hansler. ${ }^{9}$

IV. Reducing sugar determination-The presence of reducing sugar was determined using Fehling's solution test described by Ramalingan..$^{10}$

V. Dietary fibre determination was done by the procedure described by Okaka et al. ${ }^{11}$

VI. Determination of calcium and magnesium was done by a method similar to that of Udoh et al. ${ }^{12}$

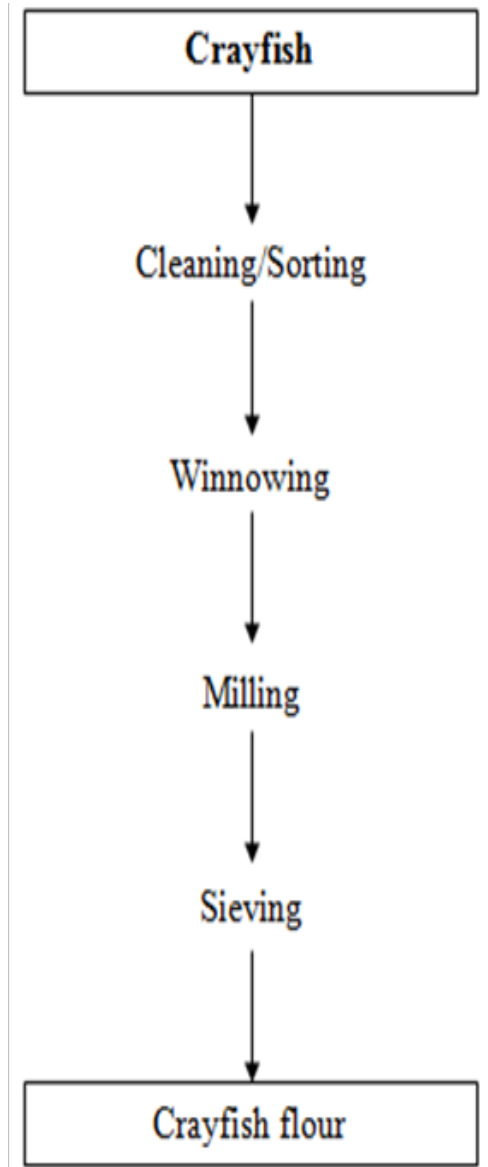

Figure 3 Flow chart of crayfish flour processing.

\section{Vitamin analysis}

a) Vitamin C (Ascorbic acid) was determined using the method described by Onwuka. ${ }^{7}$

b) Vitamin A was determined by the method of Delia and Meoko.

\section{Anti-nutrient Analysis}

i. Phytate was carried out using the method described by Onwuka.?

ii. Tannin content was ascertained using the Denis Colorimetric method described by Kirk et al. ${ }^{13}$ Determination of Oxalate was done using the technique described by Onwuka. ${ }^{7}$

\section{Sensory Evaluation}

Sensory evaluation of the five composite diets and a commercial product (Nutrend) were assessed on the taste, appearance, aroma, 
texture, colour and overall acceptability by a 30 semi-trained adult panelist which includes mothers with children age 6 to 24 months and post graduate student in Imo State University Owerri using a 9-point hedonic scale Williams which ranged between 1 (dislike extremely) and 9 (like extremely). The range method of statistical analysis was applied for the test of the significance to find the preference.

$$
\begin{aligned}
& \text { 9=Like extremely } \\
& 8=\text { Like very much } \\
& 7=\text { Like moderately } \\
& 6=\text { Like slightly }
\end{aligned}
$$

$5=$ Neither like non-dislike

$4=$ Dislike slightly

$3=$ Dislike moderately

$2=$ Dislike very much

$1=$ Dislike extremely.

\section{Statistical analysis}

The data on the composite diets were statistically analyzed using

\begin{tabular}{|c|c|c|c|c|c|c|}
\hline Samples & Millet (g) & Breadfruit (g) & Crayfish (g) & Skimmed milk powder (g) & Sugar (g) & Salt (g) \\
\hline A NUTREND & \multicolumn{6}{|c|}{ (Commercial Product) } \\
\hline B SMSB (48h/96h) & 70 & 30 & 5 & 5 & 2 & $\mathrm{I}$ \\
\hline C SMSB (72h/I20h) & 70 & 30 & 5 & 5 & 2 & $\mathrm{I}$ \\
\hline D SMSB $(96 h / / 44 h)$ & 70 & 30 & 5 & 5 & 2 & $\mathrm{I}$ \\
\hline E MB & 70 & 30 & 5 & 5 & 2 & 1 \\
\hline
\end{tabular}
one way analysis of variance (ANOVA) and Duncan's multiple range tests was used to separate the means. ${ }^{14}$

Table I Formulation of composite diets

A NUTREND- Commercial product

B SMSB-Sprouted millet at $48 \mathrm{~h} \pm$ sprouted breadfruit at $96 \mathrm{~h}$

C SMSB-Sprouted millet at $72 \mathrm{~h} \pm$ sprouted breadfruit at $120 \mathrm{~h}$

D SMSB-Sprouted millet at $96 \mathrm{~h} \pm$ sprouted breadfruit at $144 \mathrm{~h}$

E MB-Unsprouted millet \pm breadfruit

\section{Results and discussion}

Proximate composition of sprouted breadfruit and millet composite diets at varying times

The result of proximate analysis of composite diets made from Treculia africana and millet flours at different sprouting time are presented in Table 2 .

Moisture content: The values of the moisture contents of the unsprouted and sprouted flour samples ranged from 6.97\%-6.97\% (Table 1). Sprouting increased with C (70:30; sprouted at $72 \mathrm{~h} / 120)$ having the highest moisture content of $6.97 \%$. The diet sample with high moisture content will have low keeping quality or shelf-life. This is because, micro-organism that cause food spoilage thrive well with adequate moisture. ${ }^{15}$ There were significant difference $(\mathrm{P}<0.05)$ between diet sample $\mathrm{A}$ and the other samples but there was no significant difference $(\mathrm{P}<0.05)$ between diet sample $\mathrm{B}$ and $\mathrm{D}$.

Ash content: Sprouting increased the ash contents of the composite diets. Diet sample C (70:30, sprouted at $72 \mathrm{~h} / 120)$ has the highest ash content of $1.59 \%$, followed by diet sample B (70:30; sprouted at $48 \mathrm{~h} / 96 \mathrm{~h})$ with ash value of $1.48 \%$. Diet sample D (70:30, sprouted at $96 \mathrm{~h} / 144 \mathrm{~h})$ has an ash value of $1.35 \%$ while diet sample E (70:30, unsprouted) millet and breadfruit had the least ash value of $1.19 \%$. Ash is a non-organic compound continuing mineral contents in the food and nutritionally aid in the metabolism of the organic compounds such as fat and carbohydrate. ${ }^{16}$ Nwabueze et al. ${ }^{17}$ reported higher values of $3.9 \%$ in the ash content of breadfruit (Treculiaa Africana). There were significant differences $(\mathrm{P}<0.05)$ in the ash contents of the composite diets.
Crude fibre: Sprouting increased the fibre values of the composite diets $\mathrm{C}, \mathrm{B}$ and $\mathrm{D}$ when compared with composite diet sample $\mathrm{E}$ which is the unsprouted diet sample with a lower crude fibre content of $2.26 \%$. The low crude fibre value of the sprouted diet samples was due to dehulling. Dehulling of seeds, grains reduces their fibre content. ${ }^{18}$ Crude fibre is known to aid digestive system of human. ${ }^{19}$ Ejiofor et al. ${ }^{20}$ reported $24.50-26.50 \%$ to be the range for high or normal crude fibre food. All the diet samples were low in crude fibre content ranging from $2.26 \%-2.35 \%$ apart from diet sample A the commercial product and control which has a higher value of 4.79 . There were significant differences $(\mathrm{P}<0.05)$ between sample $\mathrm{A}$ and other samples but there were no significant differences between diet sample B and C, B and $\mathrm{D}$ and $\mathrm{D}$ and $\mathrm{E}$.

Fat content: Sprouting decreased the fat content of the composite diet samples. Diet sample C (70:30, sprouted at $72 \mathrm{~h} / 120 \mathrm{~h})$ had the least fat value of $5.11 \%$. Diet sample D (70:30, sprouted at $96 \mathrm{~h} / 144 \mathrm{~h})$ had comparable fat value of $9.11 \%$ with the commercial product (sample A) with a value of $9.17 \%$. The decrease in the fat values of the sprouted diet samples might be due to hydrolysis of lipids to free fatty acids by lipases for the synthesis of new lipid. The decrease also may be attributed to the use for fat by the microflora for energy in metabolism during sprouting. The sprouting seeding uses fat or protein as a source of energy when enough carbohydrate is not available, Anosike et al. ${ }^{21}$ and Obiakor ${ }^{22}$ indicated that the low fat values for the processed samples increased their keeping quality. It is known that the lower the fat contents of a given flour, the lower the risk of oxidative rancidity. There were significant differences $(\mathrm{P}<0.05)$ between sample A and other sample A and D.

Protein content: Sprouting decreased the protein content of the diet 
samples when compared with the unsprouted sample (diet sample E) which had the highest protein content of $28.20 \%$. The decrease in protein content of pea seed ${ }^{23}$ and legumes 4 by sprouting has been reported. However, the protein content of the commercial product which is diet sample A has the least protein value of $16.15 \%$. The daily safe levels of protein intake for infants aged 3 months to 2 years ranges from $13.00 \%-15.50 \% .{ }^{25}$ The diet samples had protein values quite above the standard values. There were significant differences $(\mathrm{P}<0.05)$ in the protein content of all the composite diets.

Table 2 Proximate composition of sprouted and unsprouted millet and breadfruit composite diets

\begin{tabular}{lllllll}
\hline Parameters/ samples & A & B & C & D & E & LSD \\
\hline Moisture (\%) & $4.90^{\mathrm{e}} \pm 0.54$ & $6.34^{\mathrm{b}} \pm 0.10$ & $5.97^{\mathrm{a}} \pm 0.38$ & $6.25^{\mathrm{b}} \pm 0.06$ & $6.09^{\mathrm{d}} \pm 0.09$ & 0.15 \\
Ash (\%) & $2.5^{\mathrm{a}} \pm 0.39$ & $1.48^{\mathrm{a}} \pm 0.06$ & $1.59^{\mathrm{b}} \pm 0.01$ & $1.35^{\mathrm{d}} \pm 0.12$ & $1.19^{\mathrm{e}} \pm 0.19$ & 0.05 \\
Fat (\%) & $9.19^{\mathrm{b}} \pm 0.32$ & $7.30^{\mathrm{d}} \pm 0.52$ & $5.11^{\mathrm{e}} \pm 1.50$ & $9.11^{\mathrm{b} \pm 0.29}$ & $11.62^{\mathrm{a}} \pm 1.41$ & 0.1 \\
Crude fibre (\%) & $4.7^{\mathrm{a}} \pm 0.85$ & $2.46^{\mathrm{c}} \pm 0.19$ & $2.56^{\mathrm{b}} \pm 0.14$ & $2.35^{\mathrm{b}} \pm 0.24$ & $2.26^{\mathrm{d}} \pm 0.28$ & 0.15 \\
Protein (\%) & $16.15^{\mathrm{e}} \pm 2.10$ & $19.66^{\mathrm{c}} \pm 0.53$ & $16.45^{\mathrm{d}} \pm 1-97$ & $23.80^{\mathrm{b}} \pm 1.32$ & $28.20^{\mathrm{a}} \pm 3.29$ & 0.15 \\
Carbohydrate (\%) & $62.46^{\mathrm{c}} \pm 1.07$ & $62.79^{\mathrm{b}} \pm 1.22$ & $67.31^{\mathrm{a}} \pm 3.24$ & $57.10^{\mathrm{b}} \pm 1.32$ & $50.65^{\mathrm{e}} \pm 4.22$ & 0.29 \\
Energy (Kcal) & $350.96^{\mathrm{e}} \pm 2.85$ & $359.01^{\mathrm{b}} \pm 0.75$ & $355.42^{\mathrm{d}} \pm 0.86$ & $360.05^{\mathrm{b}} \pm 1.21$ & $361.25^{\mathrm{a}} \pm 1.75$ & 1.42 \\
Starch (\%) & $5.93^{\mathrm{d}} \pm 0.18$ & $7.14^{\mathrm{b} \pm 0.36}$ & $6.53^{\mathrm{c}} \pm 0.09$ & $4.24^{\mathrm{e}} \pm 0.93$ & $7.82^{\mathrm{a}} \pm 0.67$ & 0.1 \\
Reducing sugar (\%) & $8.24^{\mathrm{a}} \pm 1.51$ & $4.69^{\mathrm{c}} \pm 0.08$ & $5.17^{\mathrm{b}} \pm 0.14$ & $3.81^{\mathrm{d}} \pm 0.47$ & $2.40^{\mathrm{e}} \pm 1.10$ & 0.1 \\
Dietary fibre (\%) & $48.29^{\mathrm{c}} \pm 0.25$ & $50.28^{\mathrm{b}} \pm 0.64$ & $55^{\mathrm{a}} \pm 2.75$ & $46.76^{\mathrm{d}} \pm 0.94$ & $43.99^{\mathrm{e}} \pm 2.18$ & 0.34 \\
\hline
\end{tabular}

\section{A-Commercial product (NUTREND)}

B-70\% millet flour $\pm 30 \%$ breadfruit flour at $48 \mathrm{~h} / 96 \mathrm{~h}$ sprouting time for millet \& breadfruit respectively.

C-70\% millet flour $\pm 30 \%$ breadfruit flour at $72 \mathrm{~h} / \mathrm{I} 28 \mathrm{~h}$ sprouting time for millet and breadfruit respectively.

D- $70 \%$ millet four $\pm 30 \%$ breadfruit flour at $96 \% / 144 \mathrm{~h}$ sprouting time for millet and breadfruit respectively.

E-70\% millet flour $\pm 30 \%$ breadfruit flour (unsprouted).

Note: Means in the same row with the same superscript are not significant different at $(\mathrm{P}<0.05)$. The means were separated using significant difference finisher's test.

Carbohydrate content: Sprouting increased the carbohydrate contents when compared with the unsprouted diet sample (sample E) with a carbohydrate content of 50.63\%. Diet sample B (70:30, sprouted at $48 \mathrm{~h} / 96 \mathrm{~h}$ ) had a carbohydrate content of $62.79 \%$ which was comparable with sample A (commercial product, NUTREND) which had a carbohydrate content of $62.46 \%$. Sprouting increased the carbohydrate content of diet sample D (70.30, sprouted at $96 \mathrm{~h} / 144 \mathrm{~h})$ slightly above that of sample E (unsprouted diet sample). The increase in carbohydrate content may be due to the fact that it was obtained by difference. There were significance difference $(\mathrm{P}<0.05)$ between sample A and the other diet samples.

Energy content: The food energy values of the composite diet ranged from $355.45-361.25 \mathrm{kal}$ (Table 2). These values were higher than the commercial product food energy value of 350.96kal but lower than the value of diet sample E (Unsprouted diet sample) which had a value of $361.25 \mathrm{kal}$ but the values were almost the same in all the diets including the commercial product (sample A). The food energy value resulted from the high carbohydrate content. The food energy value includes the fibre content of the carbohydrate. ${ }^{26}$ There were significance $(\mathrm{P}<0.05)$ between sample $\mathrm{A}$ and the other diet samples but there was no significant difference between sample B and D and $\mathrm{D}$ and $\mathrm{E}$.

Starch content: Sprouting reduced the starch content of the sprouted diet samples as the sprouting time increased. The values range from 7.82 (unsprouted diet sample) to 4.24 for diet sample D (70:30, sprouted at $96 \mathrm{~h} / 144 \mathrm{~h}$ ). Although the starch content of the sprouted diet samples reduced as the sprouting time increased but the starch content of the sprouted duet samples B and C were higher than the commercial product (sample A). The decreased in the starch content as a result of sprouting might be due to the hydrolyzation of starch by amylases. ${ }^{27}$ There were significance difference $(\mathrm{P}<0.05)$ in the starch content of the composite diet.

Reducing sugar: Sprouting increased the values of reducing sugar content of the composite diets. It ranged from $2.40 \%$ to $5.15 \%$. The commercial product (sample A) had a higher reducing sugar content than the sprouted diets samples. The sprouted diet samples had higher reducing sugar content than the unsprouted diet sample (sample E). Sprouting increased the reducing sugar content due to the fact that energy was needed for the growing plant. This had been proved by many researchers. ${ }^{28,29}$ There were significant difference $(\mathrm{P}<0.05)$ between sample A and the other diet samples.

Dietary fibre: Sprouting increased the dietary fibre contents of the composite diets, it ranged from $43.99 \%$ to $55 \%$. The dietary fibre contents of the sprouted diet samples $\mathrm{B}$ and $\mathrm{C}$ were higher than that of sample A (commercial product). Diet ample D with value of $46.76 \%$ was higher than the unsprouted (diet sample E) with the value of $43.99 \%$. On germination, dietary fibre fractions increased and insoluble dietary fibre fraction reduced significantly $(\mathrm{P}<0.05)$. There was marked reduction of all fibre fractions on dehulling. This agreed with the findings of Ramulu et al. ${ }^{30}$ There were significant difference $(\mathrm{P}<0.05)$ between sample $\mathrm{A}$ and the other diet samples.

\section{Mineral and vitamin content of composite diets pro- duced from millet and breadfruit}

Calcium: Sprouting decreased the calcium contents of the diet samples from $208.17 \mathrm{mg} / 100 \mathrm{~g}$ (unsprouted sample E) to $116.53 \mathrm{mg} / 100 \mathrm{~g}$ 
sprouted diet sample C). The sprouted diet samples had higher calcium content than the commercial product (sample A) but lower in calcium content than the unsprouted diet sample, E. This may be due to the fact that minerals are loft to the steep medium. Losses of $40 \%$ if the calcium from green gram and cowpea and $20 \%$ calcium those minerals from chickpeas are mostly due to leaching during steeping. ${ }^{31}$ There were significant difference $(\mathrm{P}<0.05)$ between sample $\mathrm{A}$ and the other diet samples.

Phosphorous: Sprouting increased the phosphorus contents of the composite diets from $46.78 \mathrm{mg} / 100 \mathrm{~g}$ of the diet sample $\mathrm{E}$ to $104.9 \mathrm{mg} / 100 \mathrm{~g}$. The commercial product (sample A) had a higher phosphorous content of $255.59 \mathrm{mg} / 100 \mathrm{~g}$ when compared with the sprouted and unsprouted diet samples. Sprouting improved the bioavailability of minerals such as copper, zinc, iron and phosphorus as a result of phytic acid hydrolysis. ${ }^{32}$ There were significant difference $(\mathrm{P}<0.05)$ between sample A and the other diet samples.

Magnesium: Sprouting reduced the magnesium contents of the diet samples from $158.36 \mathrm{mg} / 100 \mathrm{~g}$ of the unsprouted diet sample E to $76.82 \mathrm{mg} / 100 \mathrm{~g}$ of the sprouted diet sample (C).

Vitamin A: Sprouting increased the vitamin A contents. It ranged from $4.12 \mu / 100 \mathrm{~g}$ of the unsprouted diet sample E to $11.63 \mu / 100 \mathrm{~g}$ of the sprouted diet sample D. The sprouted diet samples had higher vitamin A content when compared with the commercial product (sample A) with a vitamin A content of $45 \mu / 100 \mathrm{~g}$. During sprouting, $\beta$-content (vitamin-A precursor) increased. ${ }^{33}$

Vitamin E: Sprouting increased the vitamin E contents of the diet samples. The vitamin E content ranged from $5.13 \mathrm{mg} / 100 \mathrm{~g}$ of the unsprouted diet sample E to $8.23 \mathrm{mg} / 100 \mathrm{~g}$ of the sprouted diet sample. The vitamin E content of the commercial product (sample A) was lower in value when compared with the sprouted diet samples. Sprouting increased a-tocopherol (Vitamin-E). ${ }^{33}$

The result of the anti-nutrient composition of the composite diets produced from sprouted millet and breadfruit

Phytate: Sprouting reduced the phytate contents from $0.24 \mathrm{mg} / 100 \mathrm{~g}$ in diet sample $\mathrm{E}$ to $0.11 \mathrm{mg} / 100 \mathrm{~g}$ of diet sample D. The enzymatic hydrolysis of phytic acid by phytase during germination was responsible for the reduced phytate and this was similar to the observation of Lorrenz. ${ }^{34}$ There were significant difference $(\mathrm{P}<0.05)$ in the phytate contents of the composite diets between sample A and the other diet samples but there was no significant difference between diet sample $\mathrm{C}$ and $\mathrm{D}$.

Tannin: Sprouting reduced the tannin contents from $0.37 \mathrm{mg} / 100 \mathrm{~g}$ in diet sample E to $0.16 \mathrm{mg} / 100 \mathrm{~g}$ in diet sample D. The reduction of tannin of tannin by sprouting has been reported Lorenz. ${ }^{34}$ There were significant difference $(\mathrm{P}<0.05)$ in the tannin contents of the composite diets between sample A and the other diet samples but there was no significant difference between diet samples C and D.

Oxalate: Sprouting reduced the oxalate contents from $0.19 \mathrm{mg} / 100 \mathrm{~g}$ in diet sample E to $0.10 \mathrm{mg} / 100 \mathrm{~g}$ in diet sample D- Decrease in Oxalate content has been indicated by Lorenz. ${ }^{34}$ There were significant difference $(\mathrm{P}<0.05)$ in the oxalate contents of the composite diet between sample $\mathrm{A}$ and the other diet samples but there was no significant difference between diet sample B \& C and diet sample C \& D.

The result of the organoleptic attributes of the composite diets produced from sprouted and unsprouted millet and breadfruit

Colour: The commercial product (sample A) had the highest colour score (8.47) but the other composite diets had comparable scores (5.76.87). All other diets had relatively high and comparable scores except diet sample D (5.7). The diet sample $\mathrm{C}$ and $\mathrm{D}$ (sprouted). There were significant difference $(\mathrm{P}<0.05)$ in the colour of the composite diets between sample $\mathrm{A}$ and the other diet samples but there were no significant difference between diet sample B, C \& E and diet sample C, D \& E.

Taste: Diet sample A (commercial product) had the best taste score (8.23). This was followed by diet sample B (6.27). The taste of this sample B was preferred most to those of others. Diet sample E (unsprouted sample) has a higher taste score (6.13) than diet samples $\mathrm{C}$ and $\mathrm{D}$ (Sprouted sample). There were significant difference $(\mathrm{P}<0.05)$ in the taste of the composite diets between sample $\mathrm{A}$ and the other diet sample B, C, D and E.

Aroma: There were variations in the aroma scores of the composite diets. Diet sample A (commercial product) had the highest score (7.6) for aroma, followed closely by diet sample B (6.1). All other composite diets had comparable scores (5.3-5.73). There were no significant difference $(\mathrm{P}<0.05)$ between sample $\mathrm{A} \& \mathrm{~B}$, diet sample $\mathrm{B}, \mathrm{C}, \mathrm{D}$ and E.

Texture: The commercial product (sample A) had the highest texture score (7.83). This was followed closely by sample B (6.23). All other composite diets had comparable scores $(5.43-5.87)$. There were significant difference $(\mathrm{P}<0.05)$ between sample $\mathrm{A}$ and the other composite diets but there were no significant difference between sample B, C, $\mathrm{D}$ and $\mathrm{E}$

Overall acceptability: The commercial product (sample A) had the highest score for acceptability. This was followed by diet sample B (6.67) then diet sample $C(6.17)$ and the unsprouted sample with score of 6.1. Diet sample D had the least score of acceptability (5.63). There were significant difference $(\mathrm{P}<0.05)$ between sample $\mathrm{A}$ and other samples but there were no significant difference between diet sample B, C, $\mathrm{D}$ and $\mathrm{E}$ and between diet sample $\mathrm{D}$ and $\mathrm{E}$ (Table 3-5).

Table 3 Mineral and vitamin contents of sprouted and unsprouted millet and breadfruit composite diets

\begin{tabular}{lllllll}
\hline Parameters/ Samples & A & B & C & D & E & LSD \\
\hline Calcium $(\mathrm{mg} / 100 \mathrm{~g})$ & $31.82^{\mathrm{a}} \pm 44.65$ & $136.16^{\mathrm{c}} \pm 2.02$ & $116.53^{\mathrm{d}} \pm 6.76$ & $165.56^{\mathrm{b}} \pm 15.16$ & $208.17^{\mathrm{a}} \pm 34.22$ & 0.15 \\
Phosphorus $(\mathrm{mg} / \mathrm{l00g})$ & $255.95^{\mathrm{a}} \pm 58.77$ & $104.9^{\mathrm{c}} \pm 8.62$ & $132.42^{\mathrm{b}} \pm 3.69$ & $81.22^{\mathrm{d}} \pm 19.21$ & $46.78^{\mathrm{e}} \pm 34.61$ & 0.15 \\
Magnesium $(\mathrm{mg} / / 00 \mathrm{~g})$ & $68.1^{\mathrm{a}} \pm 17.65$ & $106.67^{\mathrm{c}} \pm 0.45$ & $76.82^{\mathrm{d}} \pm 13.80$ & $128.31^{\mathrm{b}} \pm 9.23$ & $158.36^{\mathrm{e}} \pm 22.67$ & 0.15 \\
Vitamin & & & & & & \\
Vitamin C $(\mathrm{mg} / 100 \mathrm{~g})$ & $2.52^{\mathrm{a}} \pm 5.35$ & $14.7^{\mathrm{c}} \pm 0.12$ & $20.21^{\mathrm{b}} \pm 2.56$ & $26.54^{\mathrm{a}} \pm 5.39$ & $8.40^{\mathrm{d}} \pm 2.72$ & 0.2 \\
\hline
\end{tabular}


Table Continued.

\begin{tabular}{lllllll} 
Parameters/ Samples & A & B & C & D & E \\
Vitamin & & & & & \\
Vitamin A $(\mu / \mathrm{g})$ & $4.5^{\mathrm{d}} \pm 1.13$ & $6.73^{\mathrm{c}} \pm 0.13$ & $8.16^{\mathrm{b}} \pm 0.5 \mathrm{I}$ & $11.63^{\mathrm{a}} \pm 2.06$ & $4.12^{\mathrm{e}} \pm 1.30$ \\
Vitamin E $(\mathrm{mg} / \mathrm{l00g})$ & $4.62^{\mathrm{e}} \pm 0.68$ & $5.96^{\mathrm{c}} \pm 0.08$ & $6.75^{\mathrm{b}} \pm 0.27$ & $8.23^{\mathrm{a}} \pm 0.93$ & 0.15 & $5.13^{\mathrm{d}} \pm 0.45$ \\
\hline
\end{tabular}

A-Commercial product (NUTREND)

B-70\% millet flour $\pm 30 \%$ breadfruit flour at $48 \mathrm{~h} / 96 \mathrm{~h}$ sprouting time for millet \& breadfruit respectively.

C-70\% millet flour $\pm 30 \%$ breadfruit flour at $72 \mathrm{~h} / \mathrm{I} 28 \mathrm{~h}$ sprouting time for millet and breadfruit respectively.

D-70\% millet four $\pm 30 \%$ breadfruit flour at $96 \% / 144 \mathrm{~h}$ sprouting time for millet and breadfruit respectively.

E-70\% millet flour $\pm 30 \%$ breadfruit flour (unsprouted).

Note: Means in the same row with the same superscript are not significant different at $(P<0.05)$. The means were separated using significant difference finisher's test.

Table 4 Anti-Nutrient Composition of sprouted and unsprouted millet and breadfruit composite diets

\begin{tabular}{lllllll}
\hline Parameters/ samples & A & B & C & D & E & LSD \\
\hline Phytate $(g / / 00 \mathrm{~g})$ & $0.00^{\mathrm{e}} \pm 0.06$ & $0.18^{\mathrm{b}} \pm 0.02$ & $0.14^{\mathrm{c}} \pm 0.04$ & $0.11^{\mathrm{dc} \pm 0.09}$ & $0.24^{\mathrm{a}} \pm 0.05$ & 0.03 \\
Tannins $(g / / 00 \mathrm{~g})$ & $0.03^{\mathrm{e}} \pm 0.07$ & $0.23^{\mathrm{b}} \pm 0.02$ & $0.18^{\mathrm{c}} \pm 0.04$ & $0.16^{\mathrm{dc}} \pm 0.01$ & $0.37^{\mathrm{a}} \pm 0.08$ & 0.04 \\
Oxalate $(\mathrm{g} / 100 \mathrm{~g})$ & $0.04^{\mathrm{e}} \pm 0.04$ & $0.14^{\mathrm{b}} \pm 0.09$ & $0.12^{\mathrm{cb}} \pm 0.00$ & $0.10^{\mathrm{c}} \pm 0.09$ & $0.19^{\mathrm{a}} \pm 0.03$ & 0.02 \\
\hline
\end{tabular}

\section{A-Commercial product (NUTREND)}

B-70\% millet flour $\pm 30 \%$ breadfruit flour at $48 \mathrm{~h} / 96 \mathrm{~h}$ sprouting time for millet \& breadfruit respectively.

C-70\% millet flour $\pm 30 \%$ breadfruit flour at $72 \mathrm{~h} / 128 \mathrm{~h}$ sprouting time for millet and breadfruit respectively.

D-70\% millet four $\pm 30 \%$ breadfruit flour at $96 \% / 144 \mathrm{~h}$ sprouting time for millet and breadfruit respectively.

E- $70 \%$ millet flour $\pm 30 \%$ breadfruit flour (unsprouted).

Note: Means in the same row with the same superscript are not significant different at $(P<0.05)$. The means were separated using significant difference finisher's test.

Table 5 Organoleptic Properties of sprouted and unsprouted millet and breadfruit composite diets

\begin{tabular}{lllllll}
\hline Parameters/ Samples & A & B & C & D & E & LSD \\
\hline Colour & $3.47^{\mathrm{a}} \pm 0.80$ & $6.87^{\mathrm{b}} \pm 0.08$ & $6.10^{\mathrm{b} c} \pm 0.26$ & $5.70^{\mathrm{c}} \pm 0.44$ & $6.30^{\mathrm{b} c} \pm 0.17$ & 0.78 \\
Taste & $8.23^{\mathrm{a}} \pm 0.86$ & $6.27^{\mathrm{b}} \pm 0.02$ & $5.60^{\mathrm{b}} \pm 0.32$ & $5.33^{\mathrm{b}} \pm 0.44$ & $6.13^{\mathrm{b}} \pm 0.08$ & 1.06 \\
Aroma & $7.6^{\mathrm{a}} \pm 0.68$ & $6.10^{\mathrm{ab}} \pm 0.04$ & $5.70^{\mathrm{c}} \pm 0.17$ & $5.30^{\mathrm{db}} \pm 0.35$ & $5.73^{\mathrm{b}} \pm 0.16$ & 1.84 \\
Texture & $7.83^{\mathrm{a}} \pm 0.74$ & $6.23^{\mathrm{b}} \pm 0.02$ & $5.87^{\mathrm{b}} \pm 0.14$ & $5.53^{\mathrm{b}} \pm 0.29$ & $5.43^{\mathrm{b}} \pm 0.34$ & 1.02 \\
Acceptability & $8.63^{\mathrm{a}} \pm 0.89$ & $6.67^{\mathrm{b}} \pm 0.01$ & $6.17^{\mathrm{b}} \pm 0.21$ & $5.63^{\mathrm{c}} \pm 0.45$ & $6.10^{\mathrm{b}} \pm 0.24$ & 0.86 \\
\hline
\end{tabular}
A- Commercial product (NUTREND).
B-70\% millet flour $\pm 30 \%$ breadfruit flour at $48 \mathrm{~h} / 96 \mathrm{~h}$ sprouting time for millet \& breadfruit respectively.
C-70\% millet flour $\pm 30 \%$ breadfruit flour at $72 \mathrm{~h} / \mathrm{I} 28 \mathrm{~h}$ sprouting time for millet and breadfruit respectively.
D-70\% millet four $\pm 30 \%$ breadfruit flour at $96 \% / 144 \mathrm{~h}$ sprouting time for millet and breadfruit respectively.
E-70\% millet flour $\pm 30 \%$ breadfruit flour (unsprouted).

Note: Means in the same row with the same superscript are not significant different at $(P<0.05)$. The means were separated using significant difference finisher's test.

\section{Conclusion}

Sprouting reduced the levels of anti-nutrient in plant foods, improves organoleptic attributes and makes nutrients more available for utilization. Sprouted millet and breadfruit flours could be used as suitable supplements to the maize complementary food (pap) in Nigeria.

\section{Recommendation}

This work has provided a base line data on the processing and utilization of millet and breadfruit flour blends in the formulation of complementary diets thus bridging the gap of malnutrition in infants and children. The results of this study revealed that sprouting improves nutrient availability and decreased anti-nutrient in the flours. The use of locally available foods in the right combination to substitute for the expensive commercial complementary food should be encouraged as they are cheap and nutritious.

\section{Acknowledgements}

None. 


\section{Conflict of interest}

The author declares no conflict of interest.

\section{References}

1. WHO. Complementary feeding of young children in developing Countries. A Review of current scientific knowledge. Geneva, Switzerland World Health Organization; 1998. p. 137-140.

2. Michael C Latham. Human Nutrition in the Developing World. Rome, Italy; 1997.

3. Baldi GC. Measures for the Enhancement of Rice consumption and Diversification of rice utilization. Paper presented at the international seminar on the Diversification of rice utilization. Bangkok; 1981. 3 p.

4. Complementary feeding of young children in developing Countries. A Review of current scientific knowledge. Geneva, Switzerland: WHO; 1987. p. $3-7$.

5. Mayhew S, Penny A. Tropical and Sub-tropical foods. London and Basinostoke, UK: Macmillan Publishers Ltd; 1988.

6. Official Methods of Analysis. 7th ed. Association of official Analytical Chemists. Washington, USA; 2005. p. 800-835.

7. Onwuka GI. Food analysis and instrumentation: theory and practice. Nigeria: Naphathali prints; 2005. p. 95-96.

8. Official Methods of Analysis. Association of official Analytical Chemists. Washington, USA; 2005

9. Hansler WA. Laboratory Methods in Food Dairy Microbiology Academ ic. UK: Press London; 2013. p. 25-29.

10. Ramalingan ST. Modern Biology. Onitsha, Nigeria: Africana FEP Publishers Ltd; 1993.54 p.

11. Okaka JC, Ikegwu F. Encouraging use of dietary fibre and discouraging use of crucible fibre in mono-gastric nutrition. $J$ of Sci and Tech. 2011;17(2):2.

12. Udoh JE, Gunwale JA. Laboratory manual for the Analysis of Soil Plant and water samples. London, UK: University press; 1986. p. 260-267.

13. Kirk H, Sawyer R. Fruit Pearson Chemical Analysis of food. 8th ed. New York, USA: Churchill Livingstone; 1990.

14. Steel RGD, Torrie JH. Principles and Procedures of Statistics, A Biometric Approach. New York, USA: McGraw-Hill Books Co. Inc; 1981. p. 24-33.

15. Fox BA, Cameron AG. Food Science, Nutrition and Health. 7th ed. London, UK: Gutenbery Press Ltd; 2007. 106 p.

16. MCwilliam M. Food Fundamental. 3rd ed. Los Agelee, USA: Celiforms State University; 1978. p. 27-29.

17. Nwabueze Titus U, Nwokenna Chinwe. Inter-relationship of Physical and Physcio-chemical parameters to cooking time of Africa Breadfruit (Treculia Africana) seeds. Journal of food Agricultural Environment. 2006;4(3 and 4):84-88.
18. Rao DSS, Deosthale YG. Mineral Composite, Ionizable iron and soluble zinc in malted Grains of Pearl Millet and Ragi. Food Chemistry. 1993;11(3):217-223.

19. Ihekoronye AI, Ngoddy PO. Integrated Food Science and Technology for the Tropics. London. UK: Macmillina Publisher; 1985. p. 33-90.

20. Ejiofor MAN, Okafor JC. Prospects for Commercial Exploitation of Nigeria Indigenous Trees, vegetables, fruits and seeds through food and industrial product formulation. International Tree Crops Journal. 1997;9(2):119-129.

21. Emmanuel O Anosike, Chibogwu K Egwuatu. Bio-Chemical Changes during fermentation of Castor Oil (Ricinus Communis). Seeds for use as a seasoning agent. Plant Foods for Human Nutrition. 1981;30(34):181-185.

22. Obiakor PN. Nutritional and organoleptic evaluation of Fermented Babob, Rice Maize Flours and their Products. Nsukka: University of Nigeria; 2011.

23. Beevers L, Guernsey FS. Change in some Nitrogenous Components during the germination of pea seeds. Plant Physiol. 1996;41(9):14551458 .

24. Vanderstoep John. Effect of germination on the nutritive value of legumes. Food Technology. 1981;35(3):83-85.

25. Energy and protein requirements. Report of a joint FAO/WHO/UNU expert consultation. World Health Organ Tech Rep Ser. 1985;724:1-206.

26. Agu HO, Aluyah E. Production and chemical analysis of weaning food from maize, soybean and fluted pumpkin seed flour. Nigerian Food Journal. 2004;22(1):171-177.

27. Mohan JF, Levisetti MG, Calderon B, et al. Unique Autoreactive T-Cells recongnize insulin petides generated within the islets of langerhans in autoimmune diabetes. Nat Immunol. 2010;11(4):350-354.

28. Jaya TV, Venkataraman LV. Changes in the carbohydrate constituents of chickpea and greengram during germination. Food Chemistry. 1981;7(2):95-104

29. Kon S, Olson AC, Frederick DP, et al. Effect of different treatments on phytate and soluble sugars in california small white beans (Phaseolus vulgaris). Journal of Food Science. 1973;38(2):215-217.

30. Ramulu P, Rao PU. Effects of Processing on dietary fiber content of cereals and pulses. Plant Foods Hum Nutr. 1997;50(3):249-257.

31. Ganesh Kumar K, Venkataraman LV, Jaya TV, et al. Cooking Characteristics of some germinated legumes: changes in Phytins $\mathrm{Ca}^{++}, \mathrm{Mg}^{++}$and Pectins. Journal of Food Science. 1978;43(1):85-88.

32. Wang YYD, Fields ML. Germination of Corn and Sorghum in home to improve nutritive values. Journal of Food Science. 1978;43(4):11131115.

33. Cuddeford D (1989) Hydroponic grass. In practice 11: 211-214

34. Wilbald SM Lorri. Nutritional and Microbiological Evaluation of Fermented weaning foods. Gontebory, Sweden: Chalmers University of Technology; 1993 